\title{
PERANCANGAN SISTEM INFORMASI RADIO STRAMING SUARA SABALONG SAMALEWA BERBASIS WEB PADA DINAS KOMUNIKASI INFORMATIKA DAN STATISTIK KABUPATEN SUMBAWA
}

\author{
Jumirah $^{1}$, Jannatun Aliyah ${ }^{2}$, Jizan Qifli Ilhamdi ${ }^{3}$ \\ ${ }^{122) 3)}$ Program Studi Teknik Informatika, Fakultas Teknik, Universitas Teknologi Sumbawa \\ email:1Jumirahdewi@gmail.com,
}

\begin{abstract}
Streaming radio or commonly known as web radio, internet radio, net radio or e-radio, is actually a radio broadcast via the internet media. The streaming radio information system Suara Sabalong Samalewa works through the internet network so that it can reach any area with conditions connected with an internet network. This research aims to provide media information, education and entertainment in the form of a website with streaming radio content. This research was conducted using the waterfall metho by making direct observations into the field. With the stages of Communication (Communication), Planning (Planning), Modeling (Modeling), Construction (Construction), Deployment (Deployment).
\end{abstract}

Keywords : Radio Streaming, waterfall method

\begin{abstract}
ABSTRAK : Radio Streaming atau biasa dikenal sebagai web radio, radio internet, radio net atau e-radio, sebenarnya merupakan sebuah radio yang disiarkan melalui media internet.. Sistem informasi radio streaming Suara Sabalong Samalewa bekerja melalui jaringan internet sehingga mampu menjangkau wilayah dimana saja dengan syarat terkoneksi dengan jaringan internet. Penelitian ini bertujun Memberikan sarana media informasi, edukasi dan hiburan dalam bentuk website dengan konten radio streaming. Penelitian ini dilakukan menggunakan metode waterfall dengan melakukan observasi langsung ke lapangan. Dengan tahapan Communication (Komunikasi), Planning (Perencanaan), Modeling (Pemodelan), Construction (Konstruksi), Deployment (Penyebaran).
\end{abstract}

Kata kunci : Radio Streaming, metode waterfall

\section{PENDAHULUAN}

Perkembangan teknologi saat ini mengalami perubahan yang sangat pesat seiring dengan perkembangannya zaman. Salah satu teknologi yang berkembang untuk mengakses dan menyampaikan informasi adalah radio. Sekarang radio sudah bisa didengarkan siapa saja dan dimana saja melalui teknologi radio streaming via internet yang bertujuan supaya bisa diakases oleh para pendengar radio yang lokasinya tidak dapat menangkap siaran radio. Program studi Informatika pada Fakultas Teknik Universitas Teknologi Sumbawa merupakan program studi yang berhubungan dengan ilmu teknologi informasi dan jaringan.

Penelitian ini sebagai suatu kegiatan praktik bagi mahasiswa dengan tujuan mendapatkan pengalaman dari kegiatan tersebut, yang kemudian menjadi bekal 
dalam menjalin jenjang karir yang sesungguhnya. Dengan begitu, mahasiswa akan mendapatkan pengalaman yang kemudian jadi bekal untuk menjalani dunia kerja yang sebenarnya.

Penelitian ini dilaksanakan di Dinas Komunikasi Informatika dan Statistik Kabupaten Sumbawa Jln. Garuda No. 1 Sumbawa Besar, NTB, Indonesia. Waktu pelaksanaan magang ini selama 40 Hari. Kegiatan magang dilaksanakan dari hari senin sampai denga hari jumat, di mulai dari pukul 08:0017:00 WITA. Program studi Informatika pada Fakultas Teknik Universitas Teknologi Sumbawa merupakan program studi yang berhubungan dengan ilmu teknologi informasi dan jaringan komputer. Ilmu mengenai teknologi informasi dan jaringan komputer sangat erat kaitannya dengan segala aktuvitas yang terdapat pada bagian Dinas Komunikasi Informatika dan StatistikKabupaten Sumbawa.

Peneliti berharap dengan adanya sistem informasi radio streaming ini dapat memberikan manfaat dalam mendapatkan informasi terkini melalui radio streaming yang lokasinya tidak dapat menangkap siaran radio.

\section{TINJAUAN PUSTAKA}

Perancangan adalah penggambaran, perencanaan dan pembuatan sketsa atau pengaturan dari beberapa elemen yang terpisah ke dalam satu kesatuan yang utuh dan berfungsi Perancangan sistem dapat dirancang dalam bentuk bagan alir sistem ( system flowchart), yang merupakan alat bentuk grafik yang dapat digunakan untuk menunjukan urutan-urutan proses dari sistem (Syifaun Nafisah, 2003 : 2).
Radio merupakan sebuah teknologi komunikasi dengan cara mengirimkan sinyal melalui gelombang elektromagnetik. Teknologi komunikasi saat ini yang sudah sangat canggih sekalipun tetap menggunakan konsep-konsep dari gelombang radio tersebut. Bahkan para astronot agar bisa tetap berkomunikasi dengan bumi menggunakan sinyal radio karena gelombang elektromagnetik bisa merambat di ruang hampa udara, karena gelombang ini tidak memerlukan medium pengangkut (seperti molekul udara). Saat ini radio dapat didengarkan melalui smartphone, berbeda halnya sebelum abad k20, ketika konsep nirkabel masih dianggap kisah fiksi semata.

Radio Streaming atau biasa dikenal sebagai web radio, radio internet, radio net atau e-radio, sebenarnya merupakan sebuah radio yang disiarkan melalui media internet. Hampir semua server radio streaming tidak pernah mematikan kinerja servernya. Karena server dari radio streaming ini bisa berjalan sendiri atau bisa dikatakan auto pilot. Saat ini masyarakat sedang menggemari radio streaming, mereka bisa mendengarkan radio yang sama dimanapun dan kapanpun mereka mau. Namun syarat utama Anda bisa menjalankan radio streaming ini adalah, koneksi internet yang baik dan stabil. Audio dimainkan dari server penyiaran, dan server akan mengirimkan musik ke pendengar.

\section{Kelebihan dan kekurangan radio streaming}

1. Kelebihan Radio Streaming

Kelebhan dari radio streaming adalah semua hal yang ingin Anda dengarkan untuk menghibur diri, Anda bisa mendengarkan musik, ceramah, dan juga kesaksian-kesaksian seseorang yang bisa memotivasi Anda, dan masih banyak lagi. 
Layaknya radio FM, Anda juga bisa request lagu ke salah satu server radio streaming favorit Anda dengan mengirimkan pesan kepada mereka.

2. Kekurangan Radio Streaming

Stabilitas suara radio tergantung dengan kondisi jaringan internet. Akan merugikan apabila jika pendengar sedang berada pada wilayah tertentu dimana tidak tersedia jaringan internet yang memadai. dengan begitu, radio streaming akan sulit dinikmati.

Bagi Anda penikmat radio melalui mesin radio analog, Anda tidak akan bisa mengakses radio streaming, melainkan hanya dengan menggunaka perangkat yang hanya memiliki layanan koneksi internet saja.

Web adalah berkas yang ditulis sebagai berkas teks biasanya(plain texs) yang diatur dan dikombinasikan sedemikian rupa dengan instruksi instruksi berbasis HTML ataupun XHTML yang kadang kadang turut disisipi dengan berbagai macam bahasa skripBerkas web ini nantinya akan diterjemahkan oleh mesin browser dan ditampilkan menjadi sebuah halaman/situs web yang biasa kita lihat.

Jenis-jenis Web Antara lain :

- Situs web statis, jenis situs web yang isinya tidak diperbaharui secara berkala

- Situs web dinamis, yaitu situs yang banyak digunakan oleh perusahaan ataupun perorangan yang memag mengendalika seluruh aktifitas bisnis mereka dari dunia internet. Contonya: situs portal berita, blog dan situs
- Situs web iteraktif, situs web ini biasanya diperbaharui oleh pegguna situs web tersebut. Conntoh: situs media jaringan sosial, situs portal blogging dan situs situs lainnya

Sublime Text adalah aplikasi editor untuk kode dan teks yang dapat berjalan diberbagai platform operating system dengan menggunakan teknologi Phyton API. Sublime Text mendukung berbagai bahasa pemrograman dan mampu menyajikan fitur syntax highlight hampir di semua bahasa pemrogramman yang didukung ataupun dikembangkan oleh komunitas seperti; $\mathrm{C}, \mathrm{C}++, \mathrm{C \#}$, CSS, D, Dylan, Erlang, HTML, Groovy, Haskell, Java, JavaScript, LaTeX, Lisp, Lua, Markdown, MATLAB, OCaml, Perl, PHP, Python, R, Ruby, SQL, TCL, Textile and XML. Biasanya bagi bahasa pemrograman yang didukung ataupun belum terdukung secara default dapat lebih dimaksimalkan atau didukung dengan menggunakan add-ons yang bisa didownload sesuai kebutuhan $u s e r$.

\section{METODE PENELITIAN}

Dalam perancangan alur kerja Website Radio Streaming Suara Sabalong Samalewa penulis menggunakan metode waterfall. Menurut Pressman (2015:42) metode waterfall adalah metode klasik yang bersifat sistematis, berurutan dalam membangun software. Berikut ini gambaran tahapan proses pengerjaan dalam metode waterfall. 


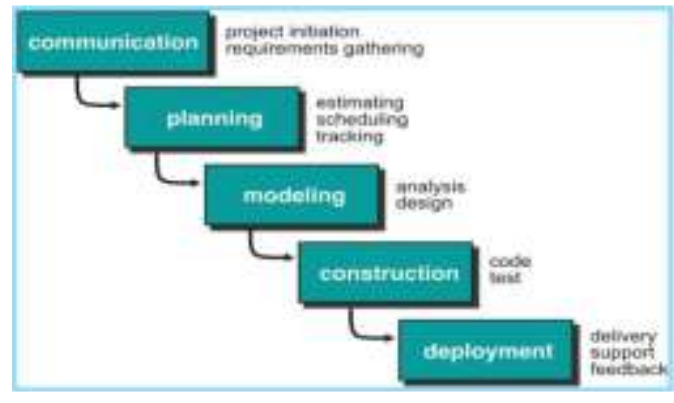

Gambar 1. Metode Waterfall

Berikut adalah fase-fase dalam model waterfall berdasarkan referensi Pressman :

\section{Communication (Komunikasi)}

Dalam kegiatan membangun website tahapan pertama yang dilakukan oleh penulis adalah bertemu dengan pihak Kantor Dinas Komunikasi Informatika dan Statistik Kabupaten Sumbawa guna mendiskusikan permasalahan yang sedang dialami, kemudian mendefinisikan spesifikasi website yang dibutuhkan oleh pihak Kantor Dinas Kominikasi Informatika dan Statistik Kabupaten Sumbawa untuk mengatasi permasalahan yang sedang dialami.

2. Planning (Perencanaan)

Dalam tahapan ini dilakukan proses perencanaan oleh penulis yang meliputi tiga proses, yaitu perhitungan estimasi waktu dan biaya yang dibutuhkan untuk membangun website ini. Kemudian proses yang kedua adalah penjadwalan pengerjaan tahapan dan proses-proses berikutnya. Dan proses yang ketiga adalah tracking/pembuatan alur kerja dari proses-proses pengerjaan yang ada.

3. Dalam tahapan ini terdapat dua proses pengerjaan yang terjadi, yaitu yang proses analisis yang meliputi analisis terhadap kebutuhan software, analisis kebutuhan hardware, dan analisis kebutuhan data yang dibutuhkan dalam pembuatan aplikasi Inventory Barang Kemudian proses yang kedua adalah perancangan yang meliputi perancangan sistem, perancangan database dan perancangan tampilan

4. Construction (Konstruksi)

Tahapan keempat dalam pembuatan website yaitu konstruksi yang meliputi proses pengkodingan.

5. . Deployment (Penyebaran)

Tahapan ini merupakan final dalam pembuatan aplikasi Inventory Barang Aplikasiyang telah dibuat harus dilakukan pemeliharaan secara berkala. Dan pada tahapan ini website siap diimplementasikan.

\section{HASIL DAN PEMBAHASAN}

\section{a. Hasil Penelitian}

Selama melakukan penelitian, peneliti dapat merancang Website yang dapat memudahkan Staff Kantor Dinas Komunikasi Informatika dan Statistika dan juga Masyarakat dalam Mendapatkan informasi

\section{b. Pembahasan}

\section{- Analisis Kebutuhan Perangkat Keras} (Hardware)

Tabel 1. Analisis Kebutuhan Perangkat Keras (Hardware) 


\begin{tabular}{|l|l|l|}
\hline NO & Nama Perangkat & Spesifikasi \\
\hline 1 & Laptop & $\begin{array}{l}\text { Memori (RAM) } \\
4.00 \text { GB }\end{array}$ \\
\hline & & $\begin{array}{l}\text { Processor Intel } \\
\text { Celeron 1.10 } \\
\text { GHz }\end{array}$ \\
\hline & & $\begin{array}{l}\text { VGA Intel } \\
\text { Chipset Onboard }\end{array}$ \\
\hline & & Harddisk \\
\hline
\end{tabular}

- Analisis Kebutuhan Perangkat Lunak (Software)

Tabel 2. Analisis Kebutuhan Perangkat Lunak (Software

\begin{tabular}{|l|l|l|}
\hline NO & Nama Perangkat & Spesifikasi \\
\hline 1 & Sistem Operasi & Windows 7 \\
\hline 2 & Texs Editor & Sumblime 3 \\
\hline 3 & $\begin{array}{l}\text { Bahasa } \\
\text { Pemprograman }\end{array}$ & PHP 5 \\
\hline 4 & WebServer & Xampp \\
\hline 5 & Basis Data & MySql \\
\hline
\end{tabular}

\section{- Diagram Alur Perancangan Radio} Streaming

Pada flowchart dibawah ini dapat diketahui bahwa penelitian dimulai dengan melakukan identifikasi masalah pada Radio Streaming Suara Sabalong Samalewa terkait sistem yang digunakan Radio Streaming Suara Sabalong Samalewa. Dari hasil identikasi ditemukan beberapa masalah yang harus difokuskan menjadi satu permasalahan yang kemudian akan menjadi dasar dalam mengembangkan sistem yang akan dibuat. Selanjutnya studi literatur dilakukan guna mencari referensi topik pembahasan yang berhubungan dengan penelitian penulis, referensi yang digunakan sebagai rujukan pada penelitian ini yang berkaitan dengan sistem radio online, radio streaming yang berbasis web. Kemudian mulai dilakukan proses Analisis kebutuhan pengguna, perancangan sistem, kemudian dilakukan pengujian. Jika ada kekurangan pada sistem maka akan dilakukan evaluasi dan perbaikan. Namun jika tidak ada yang perlu di evaluasi, kemudian terakhir implementasi. Jika semua sudah berhasil maka dibuatlah sebuah laporan penelitian untuk proses pengembangan dan perbaikan penelitian ini. Untuk tercapainya tujuan, sebuah penelitian diperlukan tahapan penelitian supaya penelsistematis. 


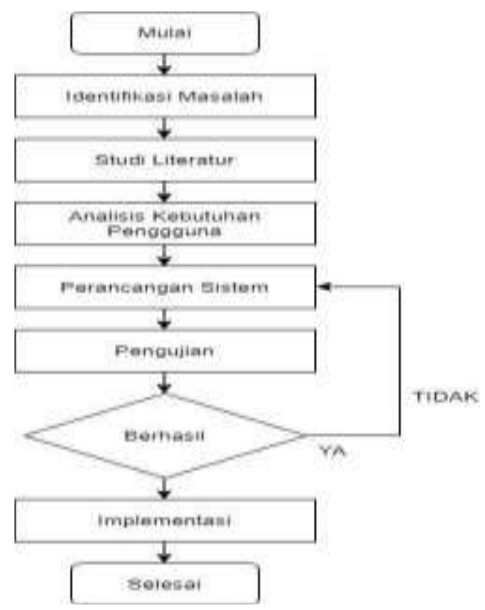

Gambar 2. Diagram Alur Perancangan

\section{- Perancangan Usecase Diagram}

Pada gambar dibawah ini adalah usecase sistem informasi Radio Streaming Suara Sabalong Samalewa. Saat membuka website, pengguna akan dihadapkan dengan pilihan menu yaitu Beranda, Berita, Galeri, Profil, Crew dan Tentang kami. Sedangkan untuk admin akan menampilkan menu user, galeri, Crew dan berita.

Admin akan memanejemen mengenai isi berita, crew dan galeri untuk ditampilkan ke dalam website.

1. Beranda

Akan menampilkan slider berupa informasi terkini, dan dibawah slider ada button play untuk mendengarkan siara radio

2. Berita
Menampilkan berita terkini mengenai Radio Streaming Suara Sabalong Samalewa

3. Galeri

Berisi dokumentasi mengenai kegiatan yang dilakukan Radio Streaming Suara Sabalong Samalewa

4. Crew

Menampilkan struktur organisasi Radio Streaming Suara Sabalong Samalewa 5. Tentang Kami

Berisi profil mengenai Radio Streaming Suara Sabalong Samalewa

6. Jadwal Siaran

Menampilkan Jadwal siaran langsung Radio Streaming Suara Sabalong Samalewa

Berikut adalah usecase diagram Radio Streaming Suara Sabalong Samalewa :

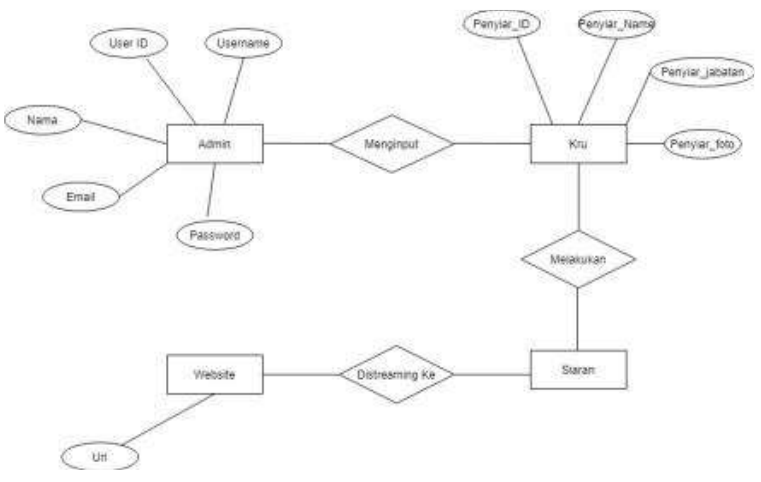

Gambar 3. Perancangan Usecase Diagram 


\section{- Perancangan Sistem Radio Streaming}

\section{Suara Sabalong Samalewa}

Penjelasan dari gambar dibawah ini bahwa cara kerja radio streaming yaitu ketika server streaming sudah dijalankan melalui software Winamp dan Edcast dari komputer penghubung server. Kemudian penyiar radio melakukan siaran melalui microphone lalu dihubungkan ke server. Suara yang masuk akan diolah dan mengalami proses encoding, lalu terhubung ke server streaming. Kemudian server yang terkoneksi dengan internet akan menyiarkan suara tersebut ke internet sehingga dapat di dengarkan pengguna secara langsung baik lewat komputer ataupun smartphone. Arsitektur perancangan sistem radio streaming Suara Sabalong Samalewa dengan server icecast sebagai berikut:

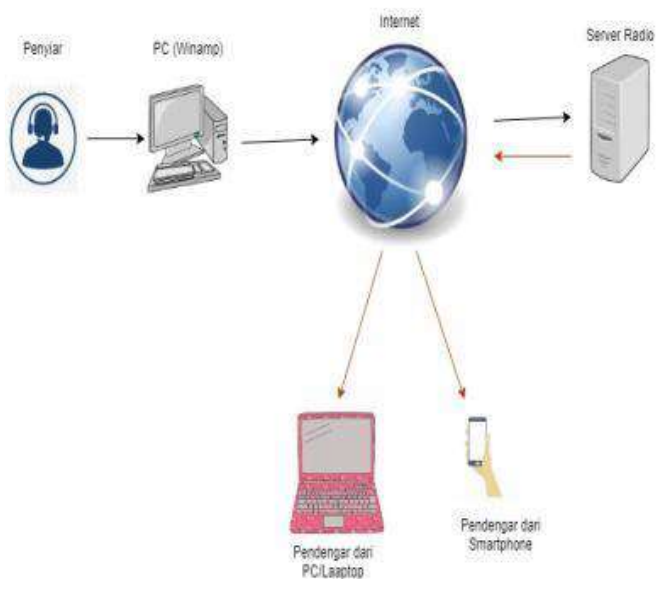

Gambar4. Perancangan Sistem

\section{- Perancangan Activity Diagram}

Berikut adalah activity diagram mendengarkan Rasio Streaming Suara Sabalong Samalewa pengunjung dibawah ini :

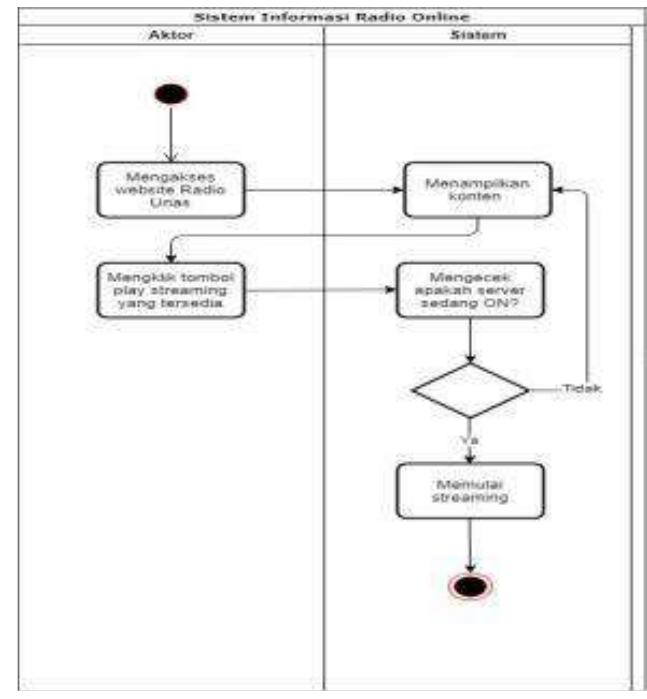

Gambar 5. Perancangan Activity Diagram

- Rancangan Entity Relatioship

\section{Diagram}

ERD (Entity Relationship Diagram) merupakan suatu model yang menggunakan susunan data yang disimpan dalam sistem secara abstrak. Berikut adalah Entity Relationship Diagram dari sistem infromasi Radio Streaming Suara Sabalong Samalewa yang dapat dilihat pada gambar berikut ini: 


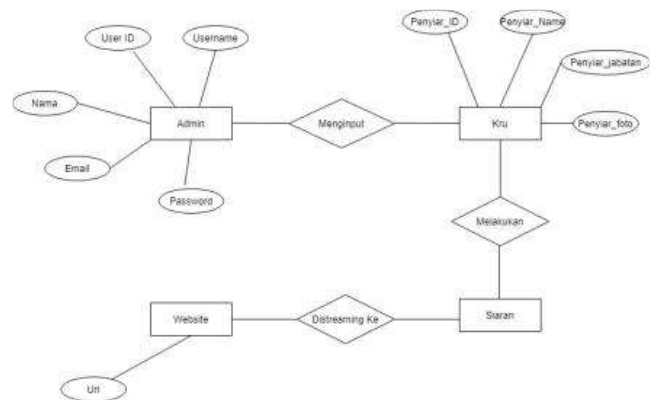

Gambar 6. Rancangan Entity Relatioship Diagram

\section{- Perancangan User Interface Radio}

\section{Streaming Suara Sabalong Samalewa}

1. Tampilan Halaman Beranda

Beranda adalah halaman yang pertama kali muncul saat pengunjung membuka website dan ingin mendengarkan siaran radio streaming Suara Sabalong samalewa. Pada website terdapat menu beranda, Podcast, Jadwal siaran Video.

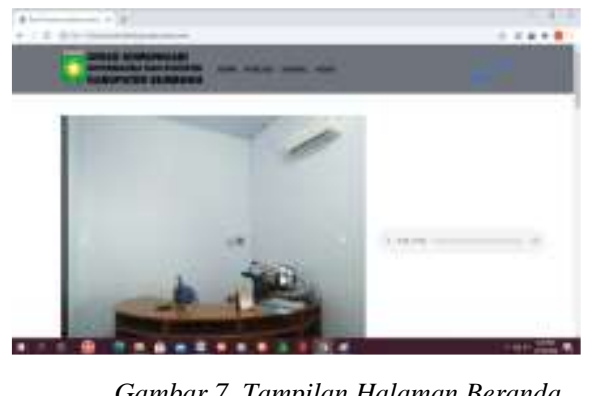

Gambar 7. Tampilan Halaman Beranda

2. Tampilan Halaman Podcast

Halaman podcast adalah suatu bentuk siaran yang biasanya terdiri dari sejumlah episode atauserial.Untuk mendengarkan siaran pengunjung website hanya perlu mengklik button play pada tampilan Radio streaming
Suara Sabalong Samalewa. Apabila Radio streaming Suara Sabalong Samalewa sedang tidak melakukan siaran langung maka pengunjung akan mendengarkan playlist lagu yang sudah di setting oleh admin mengenai kegiatan apa saja yang dilakukan Radio streaming Suara Sabalong Samalewa mulai dari seminar, pelatihan, dan lainnya.

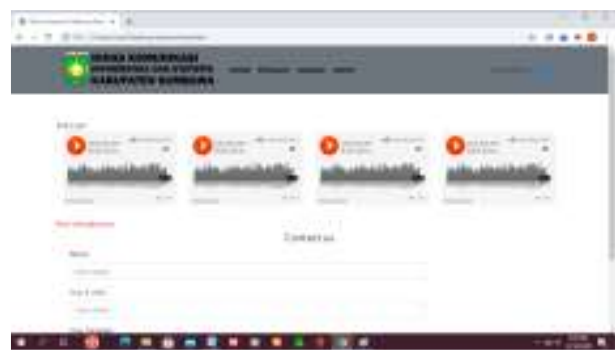

Gambar 8. Tampilan Halaman Podcast

\section{Halaman Jadwal Tampilan}

Pada menu jadwal, pengunjung bisa melihat serangkain jadwal yang ada di Radio Streaming Suara Sabalong Samalewa

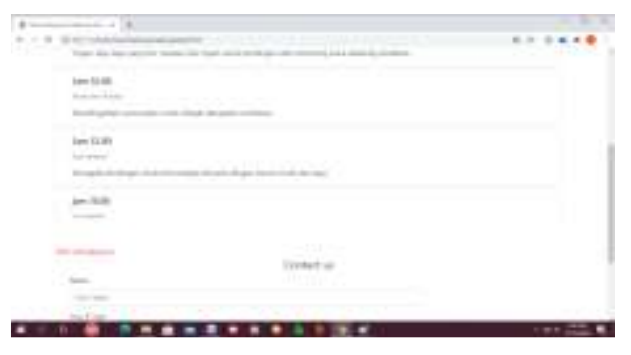

Gambar 9. Halaman Jadwal Tampilan

\section{Tampilan Halaman Video}


Pada menu video yang digunakan untuk menyimpan kegiatan sehingga pengunjung bisa melihat kegiatan apa saja yang dilakukan Radio Streaming Suara Sabalong Samalewa.

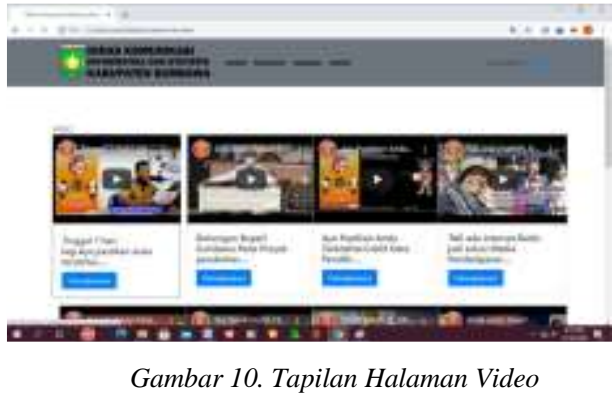

\section{KESIMPULAN DAN SARAN}

1. Kesimpulan

Kesimpulan yang dapat ditarik dari penelitian ini adalahistem informasi radio streaming Suara Sabalong Samalewa bekerja melalui jaringan internet sehingga mampu menjangkau wilayah dimana saja dengan syarat terkoneksi dengan jaringan internet dan Memberikan sarana media informasi, edukasi dan hiburan dalam bentuk website dengan konten radio streaming.

2. Saran

Saran yang peneliti harapkan dari pembaca peneliti dan pengebangan sistem tersebut dapat dikembangkan dengan desain tampilan form menu yang lebih menarik dan lebih baik lagi.

\section{DAFTAR PUSTAKA}

Kristanto, A. (2008). Perancangan Sistem

Informasi. Yokyakarta: Gava Media.

Kustiyaningsih, Y. (2011). Pemprograman

Basis Data Berbasis Web Menggunakan PHP \& MYSQL. Jakarta: Graha Ilmu

Harjanti, T. W., \& Sutendi, T. "Perancangan

Dan Implementasi Radio Streaming Berbasis Android Pada Komunitas Devilzcode” Konferensi Nasional Ilmu Pengetahuan dan Teknologi, Vol.1 (1), Agustus 2016

Maulina. F, S., "Pengembangan Aplikasi

Radio Streaming Dan On

- Demand Berbasis Website Di Radio Suara

Bangkalan Fm", Jurnal Manajemen

Informatika.Volume 9, No. 02, Tahun 2019.

Bassil, Y. 2012 A Simulation Model For Waterfall Software Develoment life Cycle. International journal Of engineering \& Technology (iJET), 2 (5): 2 